\title{
ZDROWIE I CHOROBA W DYSKURSIE RELIGIJNYM W ŚWIETLE ANALIZY RYTUAŁU UZDRAWIANIA MODLITWĄ NA MSZY ŚW. Z CHARYZMATYCZNĄ MODLITWĄ O UZdrowienie w KośCiele RZYMSKOKATOLICKIM w POLSCE ${ }^{1}$
}

\author{
Pietrzyk Anna, anna_pietrzyk@op.pl \\ Instytut Archeologii i Etnologii Polskiej Akademii Naukal. Solidarności 105, 00-140 Warszawa

\section{Abstrakt} \\ W niniejszym artykule autorka analizuje wybrane, współczesne rytuały zdrowotne praktykowane w obrębie tradycji \\ kościoła rzymskokatolickiego w Polsce, opierając się na badaniach własnych. W dobie rozkwitu biomedycyny, zastanawia \\ fakt niezwykłej popularności postawy wierzeniowej, której żywotność przejawia się nie tylko w tradycyjnych praktykach \\ religijnych, lecz także w nowych tekstach zachowań religijno - zdrowotnych propagowanych w obrębie grup Katolickiej \\ Odnowy w Duchu Świętym. Przyczyną tego może być fakt, że w dyskursie religïnym uzdrowienie jest czymś więcej, niż \\ ma do zaoferowania nowoczesna medycyna. Jest doświadczeniem religijnym, doświadczeniem sacrum, przeżywanym \\ w sposób indywidualny i zarazem kolektywny (analizowane, zapamiętywane i publicznie odtwarzane za pomocą istnie- \\ jących we wspólnocie wzorców narracji o uzdrowieniu).
}

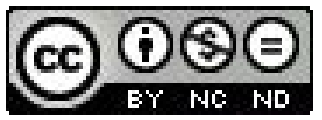

Słowa kluczowe: uzdrowienie duchowe, rytuat, sensualizm, sacrum, numinosum, modus memorandi, decorum

Health and sickness in the religious discourse, in the light of an analysis of the healing through prayer ritual observed during a Holy Mass including a charismatic prayer for healing at the Roman-Catholic Church in Poland

\section{Abstract}

Based on her own research, the author analyses some modern health rituals observed in the Roman-Catholic Church in Poland. In the times of thriving biomedicine, it is surprising how extremely popular the religious attitude is, manifested not only through traditional religious practices, but also presented in new texts about religious and pro-health behaviour, propagated by the Catholic Charismatic Renewal groups. It may result from the fact that in the religious discourse, healing is something more than modern medicine has to offer. It is a religious experience, an experience of the sacrum, lived through individually and collectively at the same time (analysed, remembered and publicly recreated through stories about healing, spread in the community).

Key words: spirituals healing, rytual, sensualizm, sacrum, numinosum, modus memorandi, decorum

W niniejszym artykule analizuję wybrane rytuały i wierzenia zdrowotne praktykowane w obrębie tradycji kościoła rzymskokatolickiego w Polsce, opierając się na badaniach własnych przeprowadzonych na obszarze Łodzi oraz zgromadzonych materiałach zastanych, dotyczących całej Polski². W dobie rozkwitu biomedycyny, zastanawia fakt niezwykłej popularności postawy wierzeniowej. Wyrazem tego są tradycyjne praktyki religijne dotyczące choroby oraz nowe praktyki zdrowotne propagowane w obrębie ruchu Charyzmatycznej Odnowy w Duchu Świętym.

Za Anną Engelking, pod pojęciem rytuału rozumiem: ,„sformalizowany rodzaj obrzędu, czyli działań indywidualnych bądź zbiorowych, często podejmowanych publicznie i uroczyście, mających charakter przede wszystkim symboliczny. Działania te zawsze wiążą się ze sferą religijna, magiczną czy też symboliczną", którą przeciwstawia się sferze profanum³.

Opisując religijne rytuały zdrowotne należy mieć na uwadze kontekst kultury. Każdy rytuał jest bowiem „,'zanurzony« w określonym systemie światopoglądowym - dokonuje się w obrębie pewnego sposobu myślenia i wierzeń ludzi w nim uczestniczących" ${ }^{\prime \prime}$, w tym przypadku kultury Polaków identyfikujących się z Kościołem rzymskokatolickim. Jak w $2013 \mathrm{r}$.

1 Artykuł powstał przy wsparciu finansowym Instytutu Archeologii i Etnologii PAN w ramach konkursu Adulescentia est tempus discendi

2 Większość materiałów z Łodzi została zebrana w trakcie obserwaçi uczestniczącej podczas mszy z modlitwą o uzdrowienie, które odbywają się w każdą ostatnią niedzielę i poniedziałek miesiąca w kościele 0. Jezuitów przy ul. Sienkiewicza 60, organizowane we wspóppracy z Ośrodkiem Odnowy w Duchu Świętym w Łodzi.

3 A. Engelking, Rytuaty stowne w kulturze ludowej. Próba klasyffikacij, [w:] J. Bartmiński, R. Grzegorczyk (red.), Jezyk a kultura, t. 4, Wroclaw 1995, s.75.

4 Zob. Tamże, s. 76.

OGRODY NAUK I SZTUK NR 2014 (4) 
wykażemy, wyobrażenia, które tworzą „teoretyczne zaplecze” tych rytuałów, to treści charakterystyczne dla światopoglądu, nazywanego przez badaczy światopoglądem religijnym, mitycznym z elementami religijności typu ludowego (takimi, jak np. sensualizm).

Rytuały przebiegają w sposób ściśle określony formalnie, dlatego można mówić o istnieniu ich scenariuszy i o ich strukturze. „Mają one również swój wyraźny cel pragmatyczny, który - zgodnie z logiką myślenia mitycznego -jest możliwy do osiagnięcia dzięki przywołaniu mocy sacrum ${ }^{\prime \prime}$. Istota działań rytualnych umożliwiających wprowadzenie zmian i przekształceń w świeckiej rzeczywistości profanum opiera się na symbolicznej reaktywacji mitycznego precedensu' ${ }^{6}$ A zatem, rytuały to działania mediacyjne umożliwiające kontakt i wzajemne oddziaływanie między sferami sacrum i profanum.

\section{ANTyCZne KORZENIE RYTUAŁU}

Na kształt zachowań zdrowotnych współczesnych katolików duży wpływ wywarł antyczny kult boga medycyny Asklepiosa oraz średniowieczny kult świętych i relikwii.

Wśród Greków, Asklepios miał opinię boga życzliwego dla ludzi, współczującego i chętnie pomagającego w potrzebie. Z tego powodu nazywano go sōtềr (wybawca). Wdzięczni wyznawcy postawili mu ponad 320 świątyń - lecznic zwanych asklepionami, w których kapłani, tzw. Asklepiadzi, nieśli pomoc medyczną ściąającym tu tłumnie pielgrzymom, jako wykonawcy woli boga - lekarza. Uzdrowiony składał tam w podzięce jakaśs ofiarę w charakterze wota. Mógł nią być marmurowy lub terakotowy wizerunek wyleczonej części ciała, rzeźbione płyty przedstawiające Asklepiosa osobiście uzdrawiającego chorego lub marmurowe stele z opisem wyleczonego przypadku. O sposobach leczenia i wierzeniach dotyczących Asklepiosa jako uzdrowiciela mówią tabliczki wotywne zawierające podziękowania za uleczenie i krótki opis okoliczności wyzdrowienia7. Opisy uzdrowień tworzą tzw. aretalogię sakralną.

Rozkwit tego rodzaju lecznictwa przypada na V w. p.n.e., niemniej kult Asklepiosa przetrwał aż do IV w. n.e., ciesząc się nieprzerwaną popularnością nawet wtedy, gdy era chrześcijańska spowodowała, wyludnienie świątyń innych bóstw. Fakt, że jeden z ojców Kościoła, św. Hieronim, potępił w swoich pismach chrześcijan uczęszczających do asklepionów i uczestniczących w tamtejszych praktykach, wskazuje, że nie było to zjawisko marginalne 8

Popularność Asklepiosa i asklepionów wśród pierwszych chrześcijan wynikać mogła z kompleksowej opieki, jaką zapewniały jego świątynie oraz dużego podobieństwa Asklepiosa i Chrystusa. Jak zauważa Jowita Jagla, „, do obu zwracano się z prośbą o łaskę, uzdrowienie duchowe i fizyczne, obaj wskrzeszali, obaj byli określani jako »Zbawca«, obaj okazywali człowiekowi miłosierdzie, za które musieli ponieść śmierć". Ich życiorysy wpisują się w topos niezwykłego dzieciństwa. Zostali poczęci i urodzili się w sposób niezwykły, ze śmiertelnych matek. W konsekwencji tych analogii, jedni utożsamiali Jezusa z Asklepiosem, inni uważali, że to co robił, czynił „,w imieniu Asklepiosa”. Zwolennicy chrześcijaństwa wskazywali jednak, iż Asklepios wskrzeszając, przywraca człowiekowi jedynie jego ludzką egzystencję, podczas gdy Chrystus oferuje więcej - życie wieczne9. W przeciwieństwie do greckiego boga, Jezus lecząc ludzi nie stosował żadnej profilaktyki ani lekarstw. Uzdrawiał poprzez słowo i gest (wyciagnięcie ręki i dotknięcie pacjenta) ${ }^{10}$. Potrafił również pomagać na odległość, nie mając żadnej styczności z chorym ani go wcześniej nie widząc.

W rezultacie zwyciężył kult chrześcijański. Jednak przyswoił sobie wiele elementów i cech antycznego kultu boga lekarza, poczynając od ikonografii Chrystusa (do złudzenia przypominającego brodatą postać Asklepiosa), gestów proksemicznych (uzdrawianie dotykiem dłoni) i inkubacji, na zwyczaju składania dziękczynnych wotów skończywszy. Gest wotywny stał się wkrótce podstawą chrześcijańskiego kultu świętych, zaś schemat tekstów starożytnej aretalogii sakralnej jeszcze dziś odbija się w tekstach współczesnych opowieści o niezwykłych uzdrowieniach, będących dziełem łaski Matki

5 Zob. Tamże, s. 75 .

6 M. Eliade, Traktat o historii religii, Warszawa 1966, s. 37-39.

7 B. Bujakowska, Spontaniczny rozwój medycyny od empirii do medycyny kaptańskiej. Medycyna jako przedmiot kultu, [w:] T. Brzeziński (red.) Historia medycyny, Warszawa 1988, s. 41, 43. L. Winniczuk, Ludzie, zwyczaje, obyczaje starożytnej Grecji i Rzymu cz. I., Warszawa 1983, s. 335, 337. T. Hergesel, Jezus cudotwórca, Katowice 1987, s. 26. J. Jagla, Wieczna prośba i dziękczynienie. O symbolicznych relacjach między sacrum i profanum w przedstawieniach wotywnych z obszaru Polski Centralnej, Warszawa 2009, s. 25.

8 L. Winniczuk, dz. cyt., s338. B. Bujakowska, dz. cyt., s. 43.

9 J. Jagla, dz. cyt., s. 27.

10 Przykładem jest opisany w Nowym Testamencie przypadek uzdrowienia kobiety, która od osiemnastu lat była pochylona i nie mogła się wyprostować. Jezus rzekł do niej: „Niewiasto, jesteś wolna od swej niemocy”, po czym położył na nią swoje ręce. W tym momencie kobieta została uleczona i wyprostowała się; zob. Łk.: 13,10-13. W podobny sposób uzdrowił trędowatego. Wyciągnął rękę, dotknął go i słowami: „bądź oczyszczony" zdjął z niego piętno nieuleczalnej choroby; zob. Łk.: 5,12-13. 
Boskiej, Jezusa Chrystusa, świętego patrona ${ }^{11}$.

Gdy cesarz Justynian (482-565) ufundował w Konstantynopolu kościół pod wezwaniem św. Kosmy i św. Damiana, świątynia ta szybko przejęła rolę dawnych asklepionów ${ }^{12}$. Chorzy spędzali tu od jednej do kilku nocy, modląc się, aby któryś ze świętych udzielił im swoich porad. „Specjalnością” obydwu patronów były powszechne w owym czasie choroby gruczołowe i owrzodzenia. Pomocy św. Kosmy i św. Damiana wzywano również w przypadku epidemii ${ }^{13}$. Był to początek kultu świętych - wyspecjalizowanych patronów od chorób w Kościele katolickim. Powiązanie świętych z konkretnymi przypadłościami nie było przypadkowe, lecz opierało się na wątkach zaczerpniętych z popularnej w średniowieczu literatury hagiograficznej i z luźno krążących o nich lokalnych legend ${ }^{14}$.

\section{SŁOWO JAKO NARZĘDZIE DZIAŁANIA I PAMIĘTANIA WE WSPÓŁCZESNYCH RELIGIJNYCH} RYTUAŁACH UZDRAWIAJĄCYCH

Zdaniem Bronisława Malinowskiego: „W każdej społeczności, zarówno wśród Trobriandczyków, jak i wśród nas, istnieje wiara, że słowo wypowiedziane w określonych okolicznościach ma moc sprawczą, wiążąca, że wypowiedź z niezmienną mocą wywołuje specyficzny skutek"15.

W religii chrześcijańskiej wiara w kreacyjną moc słowa stanowi jeden z jej fundamentów, wszak już w Starym Testamencie zawarty jest plastyczny opis stwarzania świata przez istotę boską za pomocą formuły słownej: „Niechaj się stanie $^{\prime \prime 16}$. Dlatego także i dziś, kiedy kapłan lub osoba wierząca wypowiada słowa formuły modlitewnej, nie tylko mówi, lecz również działa, ewokując określone zmiany rzeczywistości, w tym przypadku prowokując interwencję sacrum w ludzki porządek świata. Do rytuałów o takim charakterze należą współczesne rytuały zdrowotne, praktykowane w Kościele rzymskokatolickim, ti. intencyjna modlitwa indywidualna, msza z charyzmatyczną modlitwą o uzdrowienie oraz sakrament chorych.

Rytuały religijne, w przeciwieństwie do rytuałów magicznych, są rytuałami stwarzającymi o bardziej złożonej strukturze, ponieważ nadawca mówiąc, powoduje, „że moc powoduje, że tak się staje ${ }^{\prime \prime 17}$. Sposób, w jaki we współczesnych rytuałach religijnych traktowane jest słowo, odpowiada temu, który charakteryzuje tzw. społeczności tradycyjne, o światopoglądzie magiczno-religijnym.

\section{ODTWARZANIE MITYCZNEGO PRECEDENSU}

Treść Biblii, zwłaszcza Nowwego Testamentu jest sposobem, za pomocą którego jednostka wierząca usiłuje zinterpretować i opisać to, co jej się przydarzyło lub czego była świadkiem ${ }^{18}$. Dotyczy to zarówno zjawiska choroby, jak i uzdrowienia. W ten sposób współczesne opowieści zostają wplecione w prastary kanon chrześcijańskiej aretalogii sakralnej.

Aretalogia biblijna dostarcza nie tylko gotowych wzorów postrzegania, doświadczania i opisywania zjawisk, i przeżyć, lecz - jak pisze Andrzej Wejland, tworzy również wspólnotowy modus memorandi (sposób zapamiętania) zdarzenia oraz determinuje zachowania zdrowotne ${ }^{19}$. Nie chodzi tu tylko o wiarę $\mathrm{w}$ zbawienny wpływ modlitwy na powrót do zdrowia, pomyślny wynik operacji lub terapii zaordynowanej przez lekarza. W jednym ze współczesnych świadectw zapisanych przez A. Wejlanda, odnajdujemy wzorzec zachowania, który opisany zastał w Nowym Testamencie: „W ubiegłym roku zachorowałam na raka skóry. Wszyscy lekarze przynaglali mnie do szybkiej operacji, podejrzewając najgorsze - czerniaka. We wrześniu poszłam po raz pierwszy na Mszę św. z modlitwą o uzdrowienie (...). Włączyłam się do modlitw i czekałam z ufnościa, że jak ksiądz pójdzie przez kościół udzielając namaszczenia chorych, dotknę się »frędzli Jego szat«, a na pewno Jezus mi pomoże. Zrobiłam to ukradkiem, ale z pełnym zaufaniem. Po powrocie do domu oraz

11 Zob.J. Jagla, dz. cyt., s. 27, 33.

12 Jednak w przeciwieństwie do świątyń pogańskich, oferowana tutaj pomoc miała jedynie wymiar sakralny. Zob J. Jagla, dz. cyt., s. 23.

13 B. Bujakowska, dz. cyt., s. 45.

14 Dla przykładu św. Roch - patron zadżumionych, leczył za życia ludzi dotkniętych tą zarazą. Sam również zachorował, ale zdołał wyzdrowieć. W celi, w której zmarł, niesłusznie oskarżony o szpiegostwo, znaleziono kartke z napisem: „Ci, którzy zostana dotknięci zaraza, a będa wzywać na pomoc św. Rocha jako swojego pośrednika i patrona, będą uleczeni", Zob. W. Zaleski, Śzwięci na każdy dzień, Warszawa 2002, s. 474.

15 B. Malinowski, Ogrody koralowe i ich magia. Jezyk magii i ogrodnictwa, Warszawa 1987, s. $102-103$.

16 Ks. Rodzaju 1:1-31, Biblia Tysiaclecia, http://biblia.info.pl/biblia.php, 17.10.2013.

17 A. Engelking, dz. cyt., s. 76 .

18 A. P. Wejland, Wspólnota świadectwa. Charyzmatyczne opowieśsi o uzdrowieniu, [w:] K. Kaniowska, G. E. Karpińska (red), Codzienne i niecodzienne. O wspólnotowości w realiach dzisiejszej Łodzi, „Łódzkie Studia Etnograficzne” t. 43, s. 66.

19 Tamże, s. 65. 
w następnych dniach odczuwałam swędzenie w okolicy »guza«. Wcześniej nie odczuwałam takich reakcji. W następnym miesiącu również uczestniczyłam we Mszy Św. o uzdrowienie i wówczas zniknął lęk przed operacją"20.

Przytoczona narracja w sposób czytelny nawiązuje do Ewangelii św. Łukasza, opisującej przypadek kobiety, która dwanaście lat cierpiała na krwotok, ukradkiem dotknęła frędzli płaszcza Jezusa i natychmiast została uleczona ${ }^{21}$. Tak w działaniu kobiety, żyjącej ponad dwa tysiące lat temu, jak i tej współczesnej z podejrzeniem czerniaka, bardzo silnie uwidocznia się postawa sensualistyczna, charakterystyczna dla religijności typu ludowego. W sensualnym sposobie uczestnictwa w świecie, szaty Jezusa i kapłana mogą leczyć, gdyż stają się czymś więcej niż tylko okryciem. Poprzez bliski kontakt z sacrum ulegają sakralizacji, przejmując jego moc. Widać tu także silne utożsamienie kapłana - namiestnika Chrystusa na Ziemi z postacią Jezusa - lekarza ciała i ducha. Pozwala to na pełne (ti. symbolicznie skuteczne) odtworzenie sytuacji prototypowej (opisanej w Ewangelii) w realiach współczesnej mszy świętej.

Przeświadczenie o skuteczności rytuałów zdrowotnych stanowi część całego systemu psychologicznego, wspierającego się na nieuświadomionych tendencjach umysłu. W umysłowości ludzi wierzących nie ma nieprzebytej otchłani między cudownym światem, jaki otwierają przed nimi rytuały chrześcijańskie, a światem, w którym żyją. Oba światy przenikają się wzajemnie. Gest uczyniony w niebie ma takąż samą moc sprawczą na ziemi. Odpowiednio wykonany przez uprawnione do tego osoby (kapłana lub tzw. animatorów w trakcie mszy) inicjuje interwencję sił nadprzyrodzonych w ludzki porządek istnienia ${ }^{22}$.

\section{DECORUM RELIGIJNYCH RYTUAEÓW ZDROWOTNYCH}

Kreacyjną moc słowa w rytuale religijnym wzmacnia formuła, gest, kontekst sytuacyjny (określone miejsce i czas) oraz sposób, w jaki uczestnicy przygotowują się lub przygotowywani są do rytuału. Do działań tych należy: odpowiedni ubiór do kościoła, wyciszenie, czasem post, a najczęściej spowiedź, poprzedzająca uczestnictwo we mszy w intencji lub z modlitwą o uzdrowienie. Dzięki tej ostatniej, możliwe jest domknięcie rytuału przez uczestnictwo w Eucharystii (przyjęcie komunii św.), które w sposób symboliczny wzmacnia moc rytuału i konsoliduje jednostkę ze wspólnotą wiernych. W kościele rzymskokatolickim przyjęcie komunii św. traktowane jest jako pełne uczestnictwo we mszy świętej. Natomiast post ma właściwości oczyszczające. W kulturach tradycyjnych o światopoglądzie religijno-magicznym, przygotowuje człowieka na kontakt z sacrum, poprzedzając wiele działań o charakterze rytualnym. Czystość fizyczna (wstrzemięźliwość seksualna, post), jak również duchowa (spowiedź) ma istotne znaczenie. Kontakt jednostki ze sferą sacrum na to nieprzygotowanej, która nie przeszła rytualnego oczyszczenia, niesie nie tylko groźbę pozbawienia rytuału jego skuteczności, lecz co gorsza ryzyko skalania sacrum, dlatego stanowi jedno z najsurowiej przestrzeganych tabu. W kulturach tradycyjnych, sfery sacrum i profanum mają określone jakości, których nie wolno ze sobą mieszać. Z drugiej strony, przygotowania te dają wiernemu poczucie, że również jego działania przed i w czasie mszy mają wpływ na przebieg rytuału dla niego samego lub osób, w intencji których przybył na mszę, pokonując niekiedy znaczne odległości.

W rytuale kluczową rolę odgrywa także miejsce, w jakim przebiega. kościół stanowi naturalne miejsce skupienia i kontaktu z sacrum, które jest istotnym elementem działan rytualnych. Dlatego usytuowanie rytuału religijnego w obiektach sakralnych i osadzenie go w liturgii mszy św., jest ważnym czynnikiem psychologicznym wzmacniającym, czy wręcz ewokującym efekt psychoterapeutyczny, jaki daje uczestnictwo w nim. Chorzy i ich bliscy ulegają tu swoistemu stanowi oczekiwania, napięcia i koncentracji. Efekt ten wzmaga fakt, że liturgia mszy z charyzmatyczną modlitwą o uzdrowienie jest rozbudowana w stosunku do mszy odprawianych w dni powszednie i w niedziele. Średnio trwa około dwóch godzin.

Księża, a częściej świeccy pomocnicy - tzw. animatorzy - podejmują szereg czynności mających za zadanie wzbudzić wiarę w moc rytuału w tłumie wiernych. W tym celu prosza, aby osoby, które uczestniczyły we wcześniejszych mszach i uważaja, że im pomogły, podeszły do mikrofonu, aby „dać świadectwo". Każdą wypowiedź jaka wówczas pada, kończy okrzyk „Chwalmy Pana!” - wypowiadany przez animatora bądź osobę dającą świadectwo. W ten sposób uczestnicy mszy z modlitwą o uzdrowienie stają się depozytariuszami świadectwa uzdrowienia i niejako świadkami cudownej mocy rytuału.

Istotnym elementem mszy z charyzmatyczną modlitwą o uzdrowienie jest muzyka, śpiew, taniec i wykonywane, w ślad za animatorem, rytmiczne gesty. Treść śpiewanych pieśni koresponduje z oficjalnymi modlitwami o uzdrowienie:

20 Tamże, s. 60-61

21 Łk. 8,43-45, Biblia Tysiaclecia, http://biblia.info.pl/biblia.php, 17.10.2013.

22 Zob. M. Bloch, Królowie Cudotwórcy. Studium na temat nadprzyrodzonego charakteru przypisywanego władzy królewskiej zwłaszcza we Francji i w Anglii, Warszawa 1998, s. 94-95. 
obok skruchy za grzechy pojawia się prośba o wybaczenie i udzielenie łaski uzdrowienia. W tekstach pieśni akcentuje się także te same elementy działania Chrystusa - uzdrowiciela, jakie przekazała tradycyjna ikonografia religijna: słowo i gest (dotyk). Przykładem jest popularna pieśń śpiewana w trakcie spotkań modlitewnych i mszy z charyzmatyczną modlitwą o uzdrowienie zaczynająca się od słów: „Dotknij Panie moich oczu, abym przejrzał”.

Obok działań mających na celu wzbudzenie w chorych nastroju oczekiwania, skupienia, powagi oraz zaufania, wiary w moc modlitwy i miłosierdzie Jezusa Chrystusa, duży nacisk kładzie się także na zachowania konsolidujące obcych sobie ludzi, które na czas trwania mszy dają im poczucie przynależności do jednej wielkiej wspólnoty, cierpiących złączonych wiarą i nadzieją na cud. Do zachowań tych należą wspomniane wyżej wspólne modlitwy, pieśni oraz apele do zgromadzonych o otwartość i wzajemną chrześcijańską życzliwość względem siebie. Czynności te kreują atmosferę communitas, której okresowe ewokowanie towarzyszy wielu rytuałom dorocznego cyklu obrzędowego ${ }^{23}$. Do działan tych zaliczyć także można wspólne naśladowanie przez uczestników mszy gestów animatorów, pośród których znajdują się także i te oparte o bezpośredni kontakt fizyczny między zgromadzonymi wiernymi (rytmiczne klaskanie, wyciaganie rąk do góry, przed siebie, chwytanie się za ręce, kołysanie). Ich wspólne wykonywanie nie tylko konsoliduje zgromadzonych, wytwarzając rytualne communitas, lecz dodaje takiej mszy odpowiednio ekspresywnej oprawy.

Czas trwania rytuału i jego ekspresywne decorum sprawiaja, że nawet wtedy, gdy uzdrowienie nie nastąiłło, samo uczestnictwo we mszy i wysłuchanie świadectw innych osób stanowi niezwykle silne przeżycie duchowe dla osoby religijnej. Możliwość jego doświadczenia może być jedną z głównych przyczyn (obok motywacji odzyskania zdrowia), dla których na msze z charyzmatyczną modlitwą o uzdrowienie ściaggają setki, a niekiedy i tysiące wiernych przyjeżdżających nierzadko z różnych stron Polski.

Istotne znaczenie w opisywanym rytuale zdrowotnym ma także ołtarz. Jest to nie tylko przestrzeń, gdzie kapłan celebruje liturgię mszy świętej i gdzie odbywa sięjej kulminacja. W kulturach o światopoglądzie religijnym, ołtarz wyznacza punkt centralnego otwarcia - axis mundi przestrzeni sakralnej świątyni. To miejsce najświętsze, do którego dostęp mają wyłącznie osoby uprawnione do kontaktu z sacrum (kapłani), a wykonywane tu czynności rytualne zapewniają skuteczność rytuału. Przestrzeń w jego bezpośrednim sąsiedztwie, jak podest z mikrofonem, stanowi miejsce najbardziej ekspresywne pod względem emocjonalnym, w którym przebiega kulminacja theatrum rytuału zdrowotnego mszy z charyzmatyczną modlitwą o uzdrowienie. To tutaj, w trakcie trwania modlitwy, natchnieni Duchem Św. animatorzy wymieniają intencje otrzymane od wiernych drogą tradycyjną (spisane na kartkach albo przesłane w listach) lub mailową. Ich treść pozwala na znaczną indywidualizację przekazu, dzięki czemu wierny ma poczucie, że jego los został dostrzeżony i sam transcendens zwraca się do niego ustami animatora. Wprawdzie animator nie wymienia nigdy imienia ani nazwiska osoby, w intencji której odbywa się modlitwa, jednak wykorzystując informacje, jakie uzyskał w toku wcześniejszej rozmowy, listu, czy wiadomości e-mail, uwypukla te elementy sylwetki życiorysu wiernego, które wymagają interwencji sacrum. Wypowiedzi animatora mają charakter afirmacji:

Chrystus przychodzi do kobiety, która bardzo boi się trudnej operacji, jaka ją czeka... Pan napetnia ja wiara. Zabieg zakończy się pomyślnie. Chwalmy Pana!

Pod koniec mszy, eksponowane są namacalne i sugestywne dowody skuteczności modlitwy. Pokazy te, dając świadectwo uzdrowienia, jakie za sprawą Jezusa Chrystusa i Ducha Świętego właśnie się dokonało, zasiewają w zgromadzonych ziarno nadziei i wiary w wyzdrowienie, dzięki modlitwie charyzmatycznej. Wywołują żywą reakcję zgromadzonych, a wspomnienie cudownego uzdrowienia na długo zapada w pamięć wszystkich obecnych. W wielu kościołach, przy

23 Communitas to łacińskie słowo oznaczające niezhierarchizowaną społeczność, w której ludzie są równi. W odniesieniu do czynności rytualnych oznacza także ewokowanie ducha takiej wspólnoty przez szereg gestów i czynności o charakterze symbolicznym, jako signum sytuacji prototypowej, płodnego w potencjał czasu początku, czasu sacrum, którego interwencję w świat profanum usiłuje się uzyskać. Wedle Victora Turnera "Communitas zawsze jest uważane lub przedstawiane (...) jako coś ponadczasowego, wieczne teraz, chwila w czasie i jednocześnie poza czasem, lub jako stan, do którego nie stosuje się strukturalnego spojrzenia na czas", Zob. Autor Gry społeczne, pola i metafory. Symboliczne działanie w społeczeństwie, Kraków 2005, s. 201. Jest fazą naładowaną pozytywnymi emocjami, momentem a nie stanem trwałym, doświadczeniem przekształcającym, sięgającym do korzeni bytu, środkiem do celu, Zob. V. Turner, E. Turner Obraz i pielgrzymka w kulturze chrześcijańskiej, Kraków 2009, s. 221. Communitas „,niemal wszędzie uchodzi za sakralną lub »świętą « - prawdopodobnie dlatego, że przekracza i rozmywa normy rządzące ustrukturowanymi i zinstytucjonalizowanymi związkami, a towarzyszy jej doświadczenie bezprecedensowej mocy, V. Turner Proces rytualny, Warszawa 2010, s. 140. Zdaniem Victora Turnera okresowe przywoływanie tego stanu jest konieczne, ponieważ „działania strukturalne szybko stają się jałowe i mechaniczne, jeśli zaangażowani w nie ludzie nie zanurzą się okresowo w odradzającą otchłań communitas", Tamże, s. 149. W przypadku mszy z charyzmatyczną modlitwą o uzdrowienie, chodzi o symboliczne uobecnienie atmosfery wspólnotowości Ostatniej Wieczerzy, w trakcie której Chrystus zasiadał przy stole wspólnie z apostołami jak równy z równym, ustanawiając kluczowy dla w liturgii mszy św. rytuał Eucharystii - jako symbol odkupienia i życia wiecznego, a zarazem fundament nowej wiary.

OGRODY NAUK I SZTUK NR 2014 (4) 
głównym ołtarzu lub w ołtarzach bocznych wiszą wystawione na widok publiczny wota - jako znak dziękczynienia, a zarazem namacalny dowód interwencji sacrum. Ołtarz jest zatem nie tylko centrum czynności rytualnych, lecz również obszarem, gdzie koncentrują się wszystkie nadzieje i oczekiwania odnośnie skuteczności rytuału mszy i modlitwy.

Ważnym elementem rytuału jest przyjęcie komunii św. W liturgii mszy świętej, jest to chwila, w której w sposób symboliczny kapłan dokonuje uobecnienia sytuacji prototypowej. Dokonuje się ono zarówno przez adorację Najświętszego Sakramentu, symbolizującego ciało i krew Chrystusa, jak i czytanie fragmentów Pisma Świętego odnoszących się do pierwszej Eucharystii, celebrowanej przez Jezusa Chrystusa w czasie Ostatniej Wieczerzy. Jak głosi tradycja, łamiąc chleb i dzieląc go między swoimi uczniami oraz podając im do wypicia kielich wina, wypowiedział słowa stanowiące obietnicę odkupienia i życia wiecznego, zapisane przez ewangelistów i odczytywane później przez kapłana. Zdaniem Mircea Eliadego to jest właśnie istotą i celem każdego rytuału: przywoływanie czasu początku, sytuacji prototypowej. Tylko wówczas rytuał ma sens i moc prowokowania zmiany otaczającej rzeczywistości $i^{24}$. Związane jest to ze specyficznym pojmowaniem i wartościowaniem czasu przez społeczeństwa o światopoglądzie religijno-magicznym. W przeciwieństwie do nowoczesnych społeczeństw zachodniego kręgu cywilizacyjnego, czas pojmowany jest cyklicznie, a nie linearnie, biegnąc od przełomu do przełomu, jak: noc, dzień, pótnoc, południe, powracające cyklicznie pory roku, czy - jak w przypadku religii chrześcijańskiej obrządku rzymskokatolickiego narodziny, śmierć i zmartwychwstanie Jezusa. Oprócz tego, czas posiada określone jakości, które dzielą go na czas profanum, w którym normalnie osadzone jest życie człowieka oraz czas sacrum, w którym dokonało się i w dalszym ciągu może się dokonać uformowanie lub przekształcenie rzeczywistości. To czas, w którym słowa i gesty wykonane w określony sposób, mogą sprowokować interwencję sacrum w sferę profanum, po której pozostają namacalne zmiany w otaczającej rzeczywistości. Do tego świętego i płodnego w potencjał czasu, w społeczeństwach tradycyjnych odnoszą się święte opowieści ustne, czyli mity, a w społeczeństwach piśmiennych, święte księgi zawierające opisy zdarzeń prototypowych.

\section{Zdrowie, CHOROba, UZdrowienie w Katolickiej OdNowie w Duchu ŚWIĘTYM ${ }^{25}$}

Odnowa w Duchu Świętym w Kościele katolickim, zwana również Katolicką Odnową Charyzmatyczna, jest niejednolitym ruchem o zasięgu światowym. Nie ma jednego założyciela ani grupy założycieli, nie ma też listy członków. Ruch charyzmatyczny opiera się na założeniu, że - podobnie jak w Kościele pierwotnym - również i dziś chrześcijanie obdarowywani są charyzmatami, którymi służą ku zbudowaniu wspólnoty Kościoła. Odnowa w Duchu Świętym skupia ludzi świeckich w różnym wieku i z różnych środowisk, tworzących grupy modlitewne, liczące od kilku do kilkuset członków. Łączy ich chrzest w Duchu Świętym - traktowany jako podstawowe doświadczenie wiary ${ }^{26}$. Grupy te spotykają się co tydzień na spotkaniach modlitewnych, których głównym elementem jest głośna, żywa modlitwa trwająca około 2-3 godziny. Zebrania te rozpoczyna zaproszenie Ducha Świętego do prowadzenia spotkania. Kolejnymi stałymi punktami spotkania modlitewnego sa: uwielbienie Boga (ten rodzaj modlitwy przeważa), słuchanie Słowa Bożego, nauczanie, składanie osobistych świadectw przez uczestników spotkania. Grupy prowadzone są zwykle wspólnie przez duszpasterza i zespół świeckich animatorów z liderem na czele. Tak na spotkaniach modlitewnych, jak i odbywających się zazwyczaj raz w miesiącu mszach z charyzmatyczną modlitwą o uzdrowienie, ujawniają się charyzmaty. Charyzmaty (z gr. charisma - dar łaski) to nadnaturalne dary Ducha Świętego, udzielane różnym osobom dla budowania całej wspólnoty. Do charyzmatów zalicza się m.in. tzw. dary epifanijne, czyli nadzwyczajne, jak dar modlitwy o uzdrowienie, który stanowi charakterystyczny znak grup modlitewnych Odnowy w Duchu Świętym ${ }^{27}$.

24 M. Eliade, dz. cyt.

25 Ruch Charyzmatycznej Odnowy w Duchu Świętym zrodził się w sposób spontaniczny na początku XX w. w kościołach protestanckich. W latach sześćdziesiątych XX w. ożywienie charyzmatyczne dotarło do Kościoła katolickiego, owocując powstaniem pierwszych grup Charyzmatycznej Odnowy. Polscy kapłani zetknęli się z tym zjawiskiem w latach siedemdziesiątych XX w., przebywając poza granicami naszego kraju i postanowili przeniesć je na grunt polski. Dzięki temu, już od 1976 r. zaczęły powstawać pierwsze grupy modlitewne w Polsce. Zob http://www. odnowa.org/index.php/o-odnowie/jak-powstaa.html,17.10.2013. A. Grefkowicz, Historia Katolickiej Odnowy w Duchu Świętym, http://www. odnowa.jezuici.pl/szum/animatorzy-i-liderzy-mainmenu-34/struktura-historia-mainmenu-84/88-historia-katolickiej-odnowy-w-duchu-witym, 17.10.2013.

26 "Chrzest w Duchu Świętym, zwany także »wylaniem Ducha Świętego « lub »modlitwą odnowienia darów Ducha Świętego « nawiązuje do biblijnej (...) Pięćdziesiątnicy (Dz 2, 1-41). W tym dniu apostołowie otrzymali Ducha Świętego (...), czemu towarzyszyło mówienie językami i przepowiadanie Jezusa z mocą (nawróciło się ok. 3 tys. ludzi)", Idea Odnowy, http://odnowa.org/index.php?option=com_content\&view=category\&layout=blog\&id=57\&Itemid=136, 20.04.2011.

27 Zob. Idea Odnowy, http://odnowa.org/index.php?option=com_content\&view=category\&layout=blog\&id=57\&Itemid=136, 20.04 .2011$. J. Święcicki Modlitwa o uzdrowienie http://www.odnowa.jezuici.pl/szum/prowadzenie-spotkainmenu-33/modlitwa-o-uzdrowienie-mainmenu60/57-modlitwa-o-uzdrowienie, 17.10.2013. 
W tekstach Katolickiej Odnowy w Duchu Świętym: „Istnieją trzy rodzaje chorób i każdemu z nich odpowiada szczególna modlitwa o uzdrowienie. 1) Choroba cielesna - ma swe źródło w licznych przyczynach i wymaga zwykłej modlitwy o uzdrowienie fizyczne; 2) Choroba serca - spowodowana przez zranienia emocjonalne - odpowiada jej uzdrowienie wewnętrzne; 3) Choroba ducha - będąca skutkiem grzechu, którą Jezus uzdrawia poprzez wiarę i nawrócenie ${ }^{228}$. Chorobom tym odpowiadają pojęcia uzdrowienia: ciała, psychiki i duszy.

Ryc. 1. Trzy sfery uzdrowienia w rozróżniane w Katolickiej Odnowie w Duchu Świętym

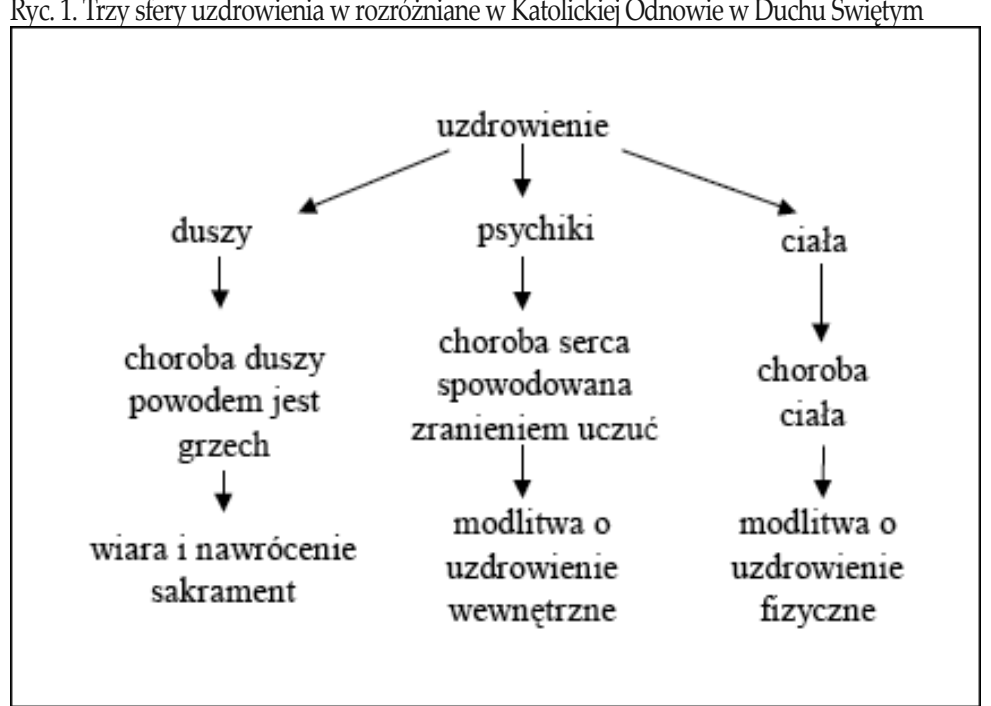

Źródło: R. Nowak, Uzdrowienie w mocy Jezusa, http://www.centrumduchowosci.pl/pliki/sow/s04.pdf, 30.08.2011.29

Zuzdrowieniami o charakterze religijnym nierozłącznie związana jest problematyka cudu. W tym kontekście Emilien Tardif dokonuje rozróżnienia na: uzdrowienia, które nie są cudami, choć są wynikiem modlitwy i cuda właściwe. Do pierwszego typu należą wszystkie przypadki, gdy Chrystus tylko przyspiesza proces zdrowienia, który jest wynikiem przyjmowania leków lub operacji. Cudami właściwymi są natomiast wszystkie te uzdrowienia, które dokonały się za sprawą Boga, a medycyna nie jest w stanie ich wyjaśnic ${ }^{30}$.

W dyskursie religijnym uzdrowienie jest czymś więcej niż ma do zaoferowania nowoczesna medycyna. Współcześni lekarze, wykorzystując zdobycze nauki i zaawansowaną technologię, leczą tylko doczesny wymiar człowieka (ciało i umysł), podczas gdy moc sacrum leczy także duszę, ofiarowując cierpiącej jednostce obietnicę życia wiecznego ${ }^{31}$.

Uzdrowienie jest doświadczeniem religijnym, doświadczeniem sacrum, przeżywanym w sposób indywidualny (wewnętrzna przemiana duchowa, nawrócenie, radość itp.) i zarazem kolektywny (analizowane, zapamiętywane i publicznie odtwarzane za pomocą istniejących we wspólnocie wzorców narracji o uzdrowieniu ${ }^{32}$. Ma ono także charakter materialny. Jest nim powrót do zdrowia cielesnego lub emocjonalnego.

Wymiar materialny ma także słowo, które wypowiedziane w określony sposób (formuła modlitwy), w określonym czasie (czas modlitwy, msza święta), miejscu (kaplica, domowe miejsce modlitwy) ma moc kreowania określonej formy rzeczywistości.

W rytuale zdrowotnym niemniej ważny jest gest (dotyk). Jest to ten sam gest nakładania rąk przez Jezusa Chrystusa, przekazany w tradycji i ikonografii religijnej.

28 E. Tardif, Czy Bóg chce cię uzdrowić?, „Szum z Nieba. Dwumiesięcznik Katolickiej Odnowy Charyzmatycznej” 2008, nr 5/ (89), s. 4-5.

29 R. Nowak, Uzdrowienie w mocy Jezusa, http://www.centrumduchowosci.pl/pliki/sow/s04.pdf, 30.08.2011.

30 E. Tardif, dz. cyt., s. 5.

31 „Uzdrowienie, które daje Jezus, sięga dalej niż może nas doprowadzić psychologia czy jakakolwiek inna nauka. O ile przebaczenie jest możliwe w samej psychoterapii, to uzdrowienie jest doświadczeniem wiary, wynikającym z łaski miłującego Boga". R. Nowak, dz. cyt., http:// www.centrumduchowosci.pl/pliki/sow/s04.pdf, 30.08.2011.

32 O wzorcach tych pisał szerzej Andrzej Welland, Zob. Tenże, dz. cyt. 
Elementem spajającym wymiar materialny i duchowy jest tutaj wiara niezbędna do tego, by uzdrowienie mogło się dokonać. Niekoniecznie musi to być wiara chorego. Może on być osobą niewierzącą i niepraktykująca. Wystarczy jednak, żeby ktoś inny modlił się żarliwie w jego intencji, aby sprowokować interwencję sacrum.

W świetle tekstów związanych z ruchem charyzmatycznym w kościele katolickim, uzdrowienie (rekonwalescencja) jest w pierwszej kolejności procesem wewnętrznym, w którym chory całkowicie zawierza swój los woli Boga, analizuje to, co go spotkało (chorobę) oraz dokonuje przewartościowania swego systemu wartości i stylu życia. Z tej perspektywy, w świadectwach uzdrowionych, dokonywana jest ewaluacja życia "przed" i „po" interwencji sacrum. Życie „przed” reinterpretowane jest jako niepełne, jałowe, chaotyczne i pełne udręk. Co wskazywać ma, że taki człowiek jest chory, zanim jeszcze pojawią się symptomy choroby ciała, ponieważ - wskutek wyznawania niewłaściwego systemu wartości (braku wiary, alkoholizmu itp.) - choruje jego dusza. Życie „po" - to życie pełne, wartościowe, właściwe, harmonijne i szczęśliwe.

Wiara w uzdrowienie modlitwą i w kreacyjną moc słowa nie wiąże się wyłącznie z uczestnictwem w mszach z charyzmatyczną modlitwą o uzdrowienie. Manifestuje się także we wpisach do ksiąg intencyjnych w klasztorze oo. Paulinów na Jasnej Górzei analogicznych ksiag wykładanych w kaplicach przyszpitalnych (na przykład w kaplicy Szpitala im. Jana Bożego Księży Bonifratrów w Łodzi). Obecna jest również w intencjach i liturgii zwykłej mszy świętej. Wskazują na to słowa formuły wypowiadanej trakcie każdej mszy w czasie adoracji ciała Chrystusa: „Panie nie jestem godna/godny abyś przyszedł do mnie, ale powiedz tylko słowo, a będzie uzdrowiona dusza moja" ${ }^{\prime \prime 3}$.

Powiązanie tematyki zdrowotnej ze sferą religijną pociąga za sobą wpisanie jej w problematykę winy, grzechu i zbawienia. We współczesnych wypowiedziach instytucji kościelnych i osób związanych ze środowiskiem Katolickiej Odnowy w Duchu Swiętym, choroba nie jest karą za grzech, choć nadal pozostaje jego konsekwencja. Jak wyjaśnia ks. Ryszard Nowak: „Konsekwencją grzechu pierworodnego jest słabość ludzkiej natury, zarówno w wymiarze ducha, psychiki, jak i ciała" ${ }^{\prime 34}$. Skutkiem tego jest podatność człowieka na choroby ciała, duszy i umysłu ${ }^{35}$.

Związek między chorobą a grzechem i karą widać w wielu tekstach współczesnych modlitw o uzdrowienie, autorstwa duchownych. Tego typu modlitwy rozpoczynają się od swoistej spowiedzi połączonej ze skruchą (żalem za grzechy), prośbą o przebaczenie oraz z wyznaniem wiary. Prośba o uzdrowienie pojawia się dopiero w dalszej części modlitw, poprzedzając zapewnienie o pełnym oddaniu wiernego i jego żarliwej wierze.

We współczesnych modlitwach autorstwa duchownych, choroba oznacza nie tylko stan fizyczny. Jest ona również metaforą życia w grzechu. Grzech jest chorobą duszy, dlatego wymaga uzdrowienia (zbawienia). Uleczenie ducha (rozgrzeszenie i zbawienie) poprzedza uzdrowienie $\mathrm{z}$ choroby w rozumieniu biomedycznym. Podstawą powrotu do zdrowia jest żarliwa wiara i bezgraniczne poddanie się boskiej woli36. Takie rozumienie problematyki choroby i zbawienia występuje również w tekstach Katolickiej Odnowy w Duchu Świętym.

Oprócz oficjalnych zinstytucjonalizowanych modlitw przekazanych przez tradycję lub napisanych przez duchownych (rozpowszechnianych w obiegu ustnym w trakcie mszy świętych, spotkań modlitewnych oraz pisemnym, za pośrednictwem modlitewników, druków na obrazkach dewocyjnych, katolickich stron internetowych itp.), spotykamy również modlitwy indywidualne. Mają one charakter prywatny, jednostkowy. Są dziełem chwili i potrzeby serca. Jeśli kiedykolwiek zostają spisane, to zwykle na użytek prywatny, ",do szuflady". Niekiedy bywają upublicznione w formie jednostkowych wpisów na forach i blogach internetowych, co nie gwarantuje im powszechnej akceptacji i rozpowszechnienia.

Modlitwy i wypowiedzi prywatne ilustrują zmianę wizerunku chrześcijańskiego Boga. Z nieobecnego Deus Otiosus, surowego władcy, sędziego i stwórcy, z którym jedynym łącznikiem była rzesza wyspecjalizowanych świętych, stał się przepełnionym miłosierdziem i przebaczeniem Ojcem ${ }^{37}$.

$33 \mathrm{~W}$ formule tej, w sposób czytelny zawiera się wiara w kreacyjną moc słowa. Słowa, które wypowiedziane z żarliwą wiarą nakłonią sacrum do interwencji w ludzki porządek świata. Narzędziem tej interwencji może być także słowo, które ma moc kreowania określonej rzeczywistości.

34 R. Nowak, dz. cyt. http://www.centrumduchowosci.pl/pliki/sow/s04.pdf, 30.08.2011.

35 Tamże.

36 Jak pisze ks. Ryszard Nowak: „Uzdrowienie jest darem Boga. Od Niego zależy, kiedy i w jaki sposób ono się dokona. Jednak człowiek ze swojej strony powinien okazać chęć współpracy z łaską Bożą. Skoro uzdrowienie jest procesem wewnętrznym, w którym godzimy się na Bożą wolę, to jest ono związane z pewnym trudem zaakceptowania warunków: uznać, że Jezus jest Panem i tylko On może mnie uzdrowić (On jest źródłem uzdrowienia), zgodzić się na sposób, w jaki chce to uczynić (wolność wewnętrzna), zgodzić się na miejsce i czas uzdrowienia (potrzebna ufność), przebaczyć (Bogu, sobie, ludziom), wzbudzić szczerą chęć nawrócenia, kroczenia za Panem (nawrócenie), pragnąć Jezusa (modlitwa, sakramenty)", Zob. R. Nowak, dz. cyt., http://www.centrumduchowosci.pl/pliki/sow/s04.pdf, 30.08.2011.

37 Zmianę tą widać wyraźnie w zmniejszeniu liczby pośredników między ludźmi a Bogiem. Współcześnie jest to głównie Matka Boska, Jezus Chrystus, św. Rita (orędowniczka w sprawach trudnych i beznadziejnych.), św. Perygryn (patron chorych na raka), św. Juda (patron od 


\section{ZAKońCZenie}

We współczesnej heterogenicznej kulturze polskiej, myślenie religijne, mityczne istnieje w sposób równoległy w stosunku do innych form percepcji otaczającego świata, takich jak myślenie potoczne i empiryczne. Jako, że bazuje na innym zestawie kodów niż myślenie naukowe (dyskursywne), wykazuje zaskakującą odporność „w obliczu nieskuteczności praktycznej" (w rozumieniu naukowej empirii) i nie daje się, ",bez zasadniczej deformacji sensu, włączyć w technologiczny porządek ludzkich zachowan'"38. Dowody wytaczane przeciw myśleniu religijnemu, wynikające z odmiennego sposobu kodowania i dekodowania rzeczywistości, jakie oferuje na przykład myślenie empiryczne, nie ważą wiele dla osób, które nie znają innego systemu kodowania niż mityczny, lub które - z pewnych względów - uznały za mało efektywne działanie oparte na wiedzy naukowej ${ }^{39}$. Z tą drugą sytuacją mamy do czynienia wówczas, gdy nowoczesna biomedycyna trafia na granicę własnych możliwości, kiedy nie może zagwarantować choremu ani pełnego powrotu do zdrowia, ani uchronić go przed wyniszczającą chorobą i śmiercią oraz zapewnić dostatecznego oparcia psychicznego dla cierpiącej jednostki i jej rodziny. Wówczas chory i jego bliscy zaczynają szukać oparcia w innym porządku myślenia, zasadzającym się na odmiennych podstawach i przyjętych wartościach.

Wiara w Chrystusa - lekarza duszy i ciała, trwa przeszło dwa tysiące lat. Tradycja ta wykazuje zaskakującą ciagłość i żywotność. Odradza się z każdym nowym świadectwem, z każdą nową jednostkową historią opowiedzianą na mszy z modlitwą o uzdrowienie, na łamach czasopism religijnych, takich jak „,Szum z Nieba”, , "Rycerze Niepokalanej” itp., na stronach internetowych parafii i wspólnot modlitewnych, albo w czasie zwykłej rozmowy. Czerpiąc korzeniami z przypowieści Nowego Testamentu, a także czasów przedchrześcijańskich nadal wywiera wpływ na współczesnego człowieka, który tak jak setki i tysiące lat temu, zmaga się z cierpieniem, chorobą i potrzebą osobistego „dotknięcia” cudu.

\section{BibliogRAFIA}

[1] Bloch M., Królowie Cudotwórcy. Studium na temat nadprzyrodzonego charakteru przypisyywanego władzy królewskiej zwłaszcza we Francji i w Anglii, Warszawa 1998.

[2] Bujakowska B., Spontaniczny rozzój medycyny od empirii do medycyny kaptańskiej. Medycyna Jako przedmiot kultu, [w:] T. Brzeziński (red.), Historia medycyny, Warszawa 1988.

[3] Eliade M., Traktat o historii religii, Warszawa 1966.

[4] Kołakowski L, Obecność mitu, Warszawa 2003.

[5] Engelking A., Rytualy stowne w kulturze ludowej. Próba klasyfikacii, [w:]J. Bartmiński, R. Grzegorczyk (red.), Język a kultura, T. 4, Wrocław 1995.

[6] Hergesel T., Jezus cudotwórca, Katowice 1987.

[7] Jagla J., Wieczna prośba i dziękczynienie. O symbolicznych relacjach między sacrum i profanum w przedstawieniach wotywnych z obszaru Polski Centralnej, Warszawa 2009.

[8] Malinowski B., Ogrody koralowe i ich magia. Język magii i ogrodnictwa, Warszawa 1987.

[9] Tardif E., Czy Bóg chce cię uzdrowić? , ,Szum z Nieba. Dwumiesięcznik Katolickiej Odnowy Charyzmatycznej” 2008, nr 5(89).

[10] Turner V., Proces rytualny, Warszawa 2010.

[11] Turner V., Turner E. Obraz i piellorzymka w kulturze chrzécijiańskiej, Kraków 2009.

[12] Turner V., Gry spoteczne, pola i metafory. Symboliczne dzzialanie w spoteczeństwie, Kraków 2005.

[13] Wejland A. P., Wspólnota świadectwa. Charyzmatyczne opowieści o uzdrowieniu, [w:] K. Kaniowska, G. E. Karpińska, Codzienne i niecodzienne. O wspólnotowości w realiach dzisiejzzei Eodzi, „Eódzkie Studia Etnograficzne” 2004, T. 43.

[14] Winniczuk L., Ludzie, zzoyczaje, obyczaje starożytnej Grecji i Rzymu cz. I., Warszawa 1983.

[15] Zaleski W., Święci na każdy dzién, Warszawa 2002.

spraw beznadziejnych), archanioł Rafael oraz lokalni patroni ośrodków religijnych słynących z uzdrowień lub działalności leczniczej. W świetle współczesnych wpisów intencyjnych oraz tradycji Nowego Testamentu, Matka Boska i Jezus Chrystus mogą być nie tylko pośrednikami, lecz również sprawcami uzdrowienia, do których bezpośrednio kierowane są prośby chorych i ich rodzin.

38 L. Kołakowski, Obecność mitu, Warszawa 2003, s. 120, 126. Przykładem równoległego funkcjonowania obok siebie dwóch porządków myślenia i kodowania rzeczywistości jest współwystępowanie dwóch różnych przekazów o powstaniu życia na ziemi, jaki oferuje religia i nauka. Religia chrześcijańska naucza, że świat powstał w 6 dni, a człowiek został ulepiony przez Boga z prochu ziemi (kreacjonizm). Badania archeologiczne i paleontologiczne wskazują na powolną ewolucję gatunków we współcześnie znane formy (ewolucionizm), a człowieka - uznawanego w chrześcijaństwie za koronę stworzenia - wyprowadzają od wspólnego przodka człowieka i małp. Wiedza o ewolucji gatunków i początkach życia na ziemi przekazywana jest powszechnie w szkołach na lekcjach biologii, tak jak wiedza o kreacji świata w 6 dni, na lekcjach religii. Ajednak nie przeszkadza to wiernym w praktykowaniu religii, a praktykowanie to nie pociąga za sobą odrzucenia treści dostarczanych przez naukę i jej kolejne odkrycia. W praktyce społecznej nie skutkuje to dysonansem poznawczym, wyniszczającym miotaniem się między jedną opcją poznania a drugą i na ogół nie pociagga za sobą refleksji na ten temat. Obydwa przekazy są przyjmowane i akceptowane takie jakie sąi używane w dwóch płaszczyznach ontologicznych: nauki i wiary.

39 Zob. L. Kołakowski, dz. cyt., s. 134

OGRODY NAUK I SZTUK NR 2014 (4) 


\section{Netografia}

[16] Ewangelia św. Eukasza, Biblia Tysiąclecia, http://biblia.info.pl/biblia.php, 17.10.2013.

[17] A. Grefkowicz, Historia Katolickiej Odnowy w Duchu Świetetym, http://www.odnowa.jezuici.pl/szum/animatorzy-i-liderzy-mainmenu-34/struktura-historia-mainmenu-84/88-historia-katolickiej-odnowy-w-duchu-witym, 17.10.2013.

[18] Idea Odnowy, http://odnowa.org/index.php?option=com_content\&view=category\&layout=blog\&id=57\&Itemid=136, 20.04.2011.

[19] Jak powstała, http://www.odnowa.org/index.php/o-odnowie/jak-powstaa.html, 17.10.2013.

[20] Ksiega Rodzaju 1:1-31, Biblia Tysiaclecia, http://biblia.info.pl/biblia.php, 17.10.2013.

[21] R. Nowak, Uzdrowienie w mocy Jezusa, http://www.centrumduchowosci.pl/pliki/sow/s04.pdf, 30.08.2011.

[22] J. Święcicki, Modlitwa o uzdrowienie, http://www.odnowa.jezuici.pl/szum/prowadzenie-spotkainmenu-33/modlitwa-o-uzdrowieniemainmenu-60/57-modlitwa-o-uzdrowienie, 17.10.2013. 